\title{
Manufacturing Against Corrosion: Increasing Materials Performance by the Combination of Cold Work and Heat Treatment for 6063 Aluminium Alloy
}

\section{Márcio Ulguim OLIVEIRA ${ }^{1}$, Luciano Volcanoglo BIEHL ${ }^{1}$, Jorge Luiz Braz MEDEIROS ${ }^{1}$, César Antonio Oropesa AVELLANEDA ${ }^{2}$, Carlos Otávio Damas MARTINS ${ }^{3}$, José de SOUZA ${ }^{4 *}$, Frederico SPORKET ${ }^{4}$}

\author{
${ }^{1}$ Universidade Federal de Rio Grande (FURG), PPMec, Av. Itália, Km 8, Campus Carreiros, Rio Grande/RS, 96201900, \\ Brasil \\ ${ }^{2}$ Universidade Federal de Pelotas (UFPel), R. Gomes Carneiro, 1, Pelotas/RS, 96010610, Brasil \\ ${ }^{3}$ Universidade Federal de Sergipe (UFS), P2CEM, Av. Marechal Rondon, S/N, São Cristóvão/SE, 49000001, Brasil \\ ${ }^{4}$ Fundação Liberato, Diretoria de Pesquisa e Produção Industrial (DPPI) Rua Inconfidentes, 395, Novo Hamburgo/RS, \\ 93340140, Brasil
}

crossref http://dx.doi.org/10.5755/j01.ms.26.1.17683

Received 18 July 2018; accepted 20 November 2018

\begin{abstract}
Nowadays, the search for more reliable and less fuel consumable structures for off shore applications leads to the development of modern materials selection and manufacturing methodologies. In this sense, Aluminum alloys has increasing for structural application due to lightweight, weldability and corrosion performance. This research aims to evaluate the influence of manufacturing process of 6063 aluminum alloy on corrosion behavior in seawater medium. After the combination of heat treatment and cold work variation, the materials were analyzed by microstructural and mechanical tests. The sample also were submitted to Potentiodynamic polarization analysis. The results prove the applicability of cold work process in order to elevate corrosion performance of 6063 aluminum alloys. This can be a low cost and time consumable, alternative to increase materials performance.

Keywords: corrosion, thermomechanical treatment, aluminium alloy.
\end{abstract}

\section{INTRODUCTION}

Engineering materials always were and always will be the key point of human development. The proper manufacturing and materials selection are not only financial manners; there are an imperative to performance, safety and degradation.

Aluminum (Al) is one of the most abundant metals on earth. As indicated by its position in the electrochemical series, aluminum is a thermodynamically reactive metal; among structural metals, only beryllium and magnesium are more reactive [1].

In this sense, aluminum alloys have a major impact on structural fabrication, combining lightweight, weldability and corrosion resistant. However, cold working and heat treatment can improve these properties.

The hardening of the 6xxx series alloys results from the formation of the intermetallic $\mathrm{Mg}_{2} \mathrm{Si}$, before the excessive maintenance in to high temperatures (super aging).

This process increases the dislocation movement and relieve, decreasing materials hardenability. In addition, the $\mathrm{Mg}_{2} \mathrm{Si}$ formation has major impact on materials strength and performance $[2,3]$.

As an alternative, cold working can be a useful tool for increase surface protection [4]. Literature reported some studies about the influence of cold working on the pitting

\footnotetext{
* Corresponding author. Tel.: +55-51-35842010

E-mail address: josesouza@liberato.com.br (J. Souza)
}

corrosion resistance $[5,6]$. The effect of the cold deformation on the higher susceptibility to pitting corrosion resistance of the material were explained by two different mechanisms:

1. Associated it to the additional energy introduced to the material by deformation, decreasing the resistance of the material to localized corrosion.

2. Related the increase in pitting susceptibility to the effect of cold working on the deformed material microstructure and its grain orientation (texture).

During the cold deformation, the inclusions often act as preferential sites for defects, once non-metallic inclusions were fragmented, or micro cracks arise at the matrix/inclusion interface [5].

This paper aimed to evaluate the influence of manufacturing process of 6063 aluminum alloy on corrosion behavior in off shore applications.

Through the combination of heat treatment and cold work, we provide a significant grain refinement and $\mathrm{Mg}_{2} \mathrm{Si}$ precipitation, which increased the pitting corrosion resistance. This work is part of a scientific project, which searches for the development of more reliable off shore structures for oil and gas prospection and transportation.

\section{EXPERIMENTAL PART}

The 6063 Al-Mg-Si alloy $(0.412 \% \mathrm{Si}, 0.490 \% \mathrm{Mg}$, $\mathrm{Fe}<0.10 \%, \mathrm{Cu}<0.10 \%, \mathrm{Mn}<0.10 \%, \mathrm{Cr}<0.10 \%, \mathrm{Al}$ Balance) was analyzed in this study. 
Eighteen samples were extracted from $35 \mathrm{~mm}$ diameters bars with composition according to Table 1 .

Table 1. Composition of samples of aluminum alloy 6063

Percent composition by weight of alloy 6063

\begin{tabular}{|c|c|c|c|c|c|c|c|}
\hline $\mathrm{Si}$ & $\mathrm{Fe}$ & $\mathrm{Cu}$ & $\mathrm{Mn}$ & $\mathrm{Mg}$ & $\mathrm{Ti}$ & $\mathrm{Al}$ & $\mathrm{Rem}$ \\
\hline 0.59 & 0.23 & 0.01 & 0.01 & 0.39 & 0.02 & 98.7 & 0.027 \\
\hline
\end{tabular}

They were solubilized at $520^{\circ} \mathrm{C}$ for 1 hour, followed by rapid cooling in water for temperature maintenance. This process occurs until the samples reach $190{ }^{\circ} \mathrm{C}$.

In the next step, the samples were artificial aging, at a temperature of $190{ }^{\circ} \mathrm{C}$ for 4 hours. After the aging time, the samples were cooled until ambient temperature.

After cooled, some of the samples were separated, at this stage already constitute 6063 T6 aluminum alloy (The T6 designation applies to products that undergo no cold working after solution heat treatment, or in which the effects of cold working associated with flattening or straightening do not alter the limits of mechanical properties).

The remained samples were cold worked by cold rolling for reducing in $10 \%, 25 \%, 40 \%, 55 \%$ and $70 \%$ of cross sectioning area (Fig. 1).

The cold work improves the samples from T6 to T9 treatment, with their respective degrees of hardening.

The samples were characterized by metallographic and Vickers hardness analysis.

The final step consisted in corrosion analysis by potential electrochemistry method. The scanning starts at potential of $-2 \mathrm{~V}$ and ending at $+2 \mathrm{~V}$. The scanning rate was $0.01 \mathrm{~V} / \mathrm{s}$ with a pitch of $0.001 \mathrm{~V}$. The duration of each test was 6 min and $40 \mathrm{~s}$.

The electrolyte used was $\mathrm{NaCl}$ with a concentration of $0.5 \mathrm{~mol} / \mathrm{dm}^{3}$. The reference electrode of $\mathrm{K}_{2} \mathrm{SO}_{4}$ was connected to the principal electrolyte through a Luggin capillary, which contained a saturated solution of $\mathrm{K}_{2} \mathrm{SO}_{4}$.

\section{RESULTS}

As can be seen, the microstructure evolution shows grain size reduction and the evident formation of the $\mathrm{Mg}_{2} \mathrm{Si}$ precipitates, represented by the black spots on OM.

The SEM images show a gradual increase in the precipitates alignment and grain deformation, by the increasing of cold work deformation.

The measurement of grain size (G) ASTM was using the circular intercept method according to ASTM E 11212. It occurred with three concentric circles with summed perimeters (LT) of $1131 \mathrm{~mm}$ on an image with magnification $(\mathrm{M})$ of $100^{\mathrm{x}}$. The results are shown in Table 2.

Table 2. Determination of grain size for 6063 aluminium alloys

\begin{tabular}{|c|c|c|c|}
\hline \multirow[b]{2}{*}{ Alloy } & \multirow{2}{*}{$\begin{array}{c}\text { Number of } \\
\text { grains per line, } \mathrm{N}\end{array}$} & \multicolumn{2}{|c|}{ Grain size } \\
\hline & & $\begin{array}{c}\mathrm{N}_{\mathrm{L}}=(\mathrm{N} \times \mathrm{M}) / \mathrm{L}_{\mathrm{T}}, \\
\mathrm{mm}\end{array}$ & G \\
\hline $6063 \mathrm{~T} 6$ & 178 & 15.74 & 4.66 \\
\hline 6063 T9 $10 \%$ & 176 & 15.56 & 4.63 \\
\hline 6063 T9 $25 \%$ & 173 & 15.30 & 4.58 \\
\hline 6063 T9 $40 \%$ & 172 & 15.21 & 4.57 \\
\hline 6063 T9 55\% & 175 & 15.47 & 4.62 \\
\hline 6063 T9 $70 \%$ & 173 & 15.30 & 4.58 \\
\hline
\end{tabular}

Fig. 2 illustrates the Vickers Hardness results. Ten indentations were performed per sample, with an average distance of $250 \mu \mathrm{m}$ between adjacent points (the maximum standard deviation was less than $5 \%$ ). The hardness for alloy 6063 T6 has similar values as presented by proving the success of the heat treatment applied [7, 8].

The increase of hardness for T6 to T9 samples were related to the effect of softening by dynamic recovery, as presented by $[9,10]$. During the rolling process, the specimens showed a considerable increase in dislocation concentration.
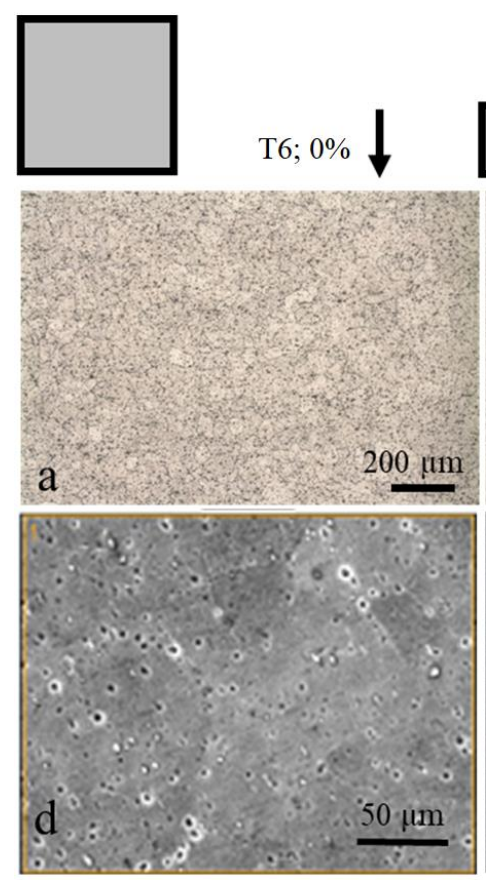
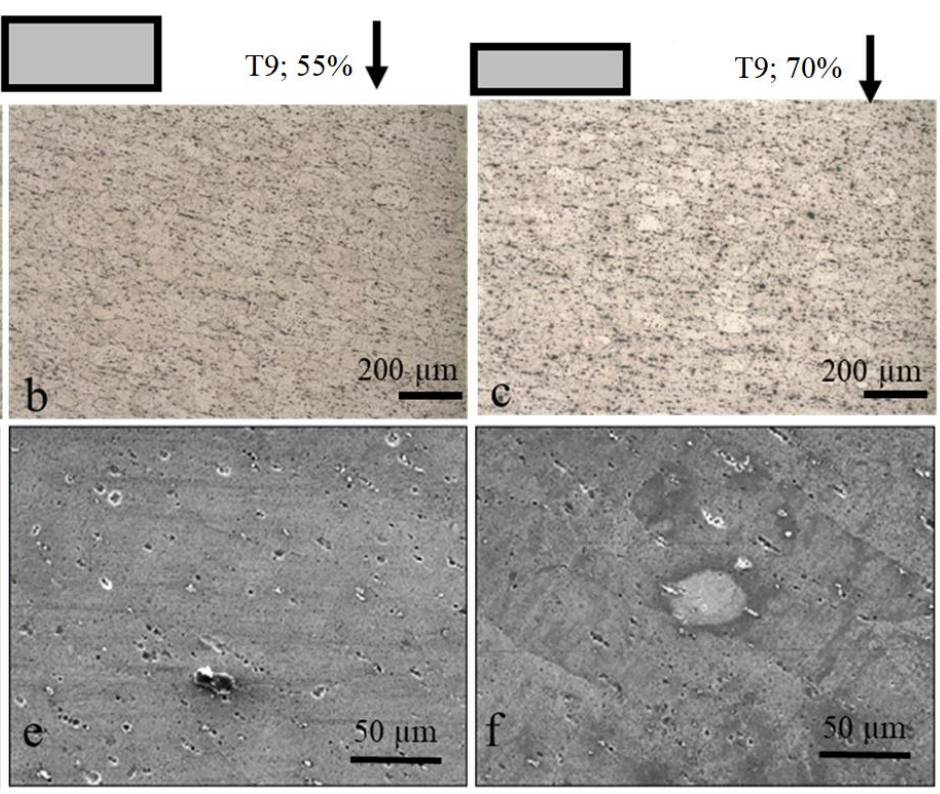

Fig. 1. Microstructural evaluation of 6063 aluminum alloys by OM and SEM 
As the effect of the rate of deformation increased, the materials hardness began to grow, according to [11].

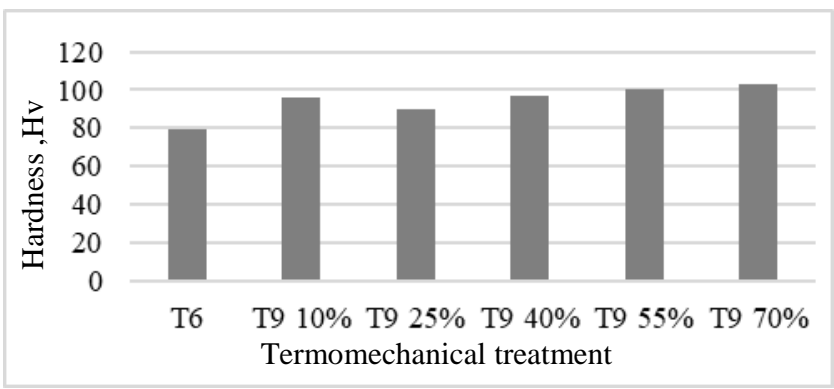

Fig. 2. Influence of thermomechanical treatment on surface hardness of 6063 aluminum alloys

Fig. 3 presents the potentiodynamic polarization curve for the 6063 T6 aluminum alloy.

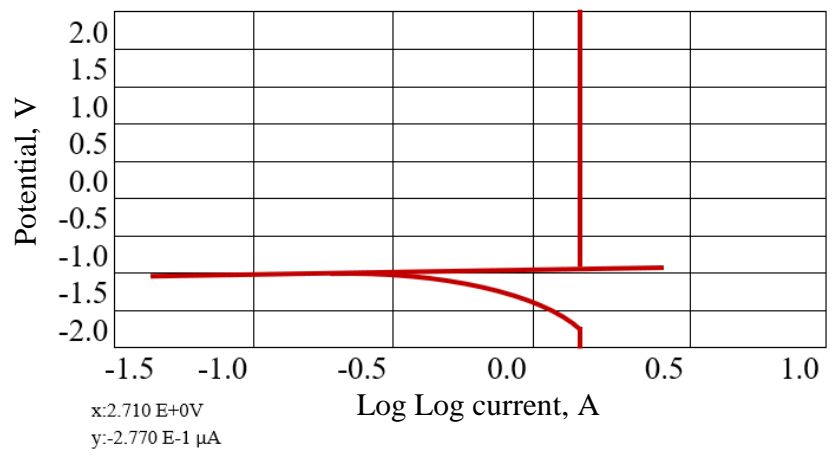

Fig. 3. Potentiodynamic polarization curve for the 6063 T6 aluminum alloy

The results indicated the beginning of pitting formation with a potential of $-1 \mathrm{~V}$ for all samples, similar to the results obtained by [12]. The corrosion current presents the most significant variations (Fig. 4). This characteristic was also noticed in Bodunrin's work (2011), where he analyzed two degrees of hardening, $20 \%$, and $35 \%$ [13].

The Fig. 4, combines the results for potentiodynamic polarization test, in $\mathrm{NaCl}$ medium, of all Aluminum alloys samples analyzed with $55 \%$ of hardening. Note that, different as hardness, the corrosion resistance (corrosion current module) was considerable affected by the degree of deformation.

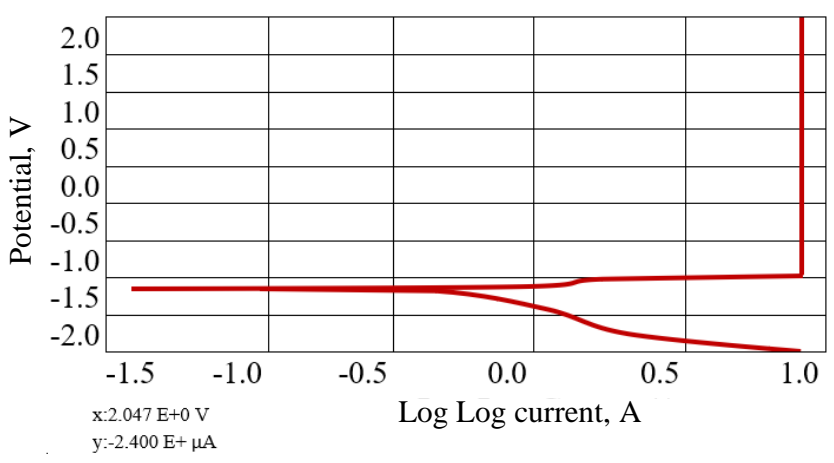

Fig. 4. Influence of thermomechanical treatment on corrosion behavior of 6063 T9 Aluminum alloys with 55\% of hardening

The results presented in this research revealed a major increasing in corrosion resistance by the application of cold working after the heat treatment process (T6 to T9).
At first (T9 10\%) the amount of deformation increases the precipitate concentration and stress concentration around the surface. As the cold work rate increases, the deformation leads to the break of passivation layers, which decrease the corrosion current to $-1.58 \mu \mathrm{A}$ (T9 $25 \%$ ). The follow increasing of deformation, has major impact in the dislocation density and secondary phenomenon's that leads to a linear increasing of corrosion current and resistance (T9 40, 55 and $70 \%$ ).

Additionally, the hardness does not present a considerable variation with the degree of deformation. This was explained by the embrittlement, resulted by the elongation of the $\mathrm{Mg}_{2} \mathrm{Si}$ precipitates.

\section{CONCLUSIONS}

The scientific findings for this research are summarized as following:

1. The influence of manufacturing process of 6063 aluminum alloy on corrosion was the focal point of this research.

2. Through the combination of heat treatment and cold work, we provide a significant grain refinement and $\mathrm{Mg}_{2} \mathrm{Si}$ precipitation, which increased the pitting corrosion.

3. The microscopic evaluation (OM and SEM) confirmed the precipitation of the $\mathrm{Mg}_{2} \mathrm{Si}$ and the grain deformation provided by cold work.

4. The cold work process has major impact on corrosion than on materials hardness.

5. The results prove the applicability of cold work process in order to elevate corrosion performance of 6063 aluminum alloys at low cost. This can be a good alternative for structural health integrity of off shore structures and equipment's.

\section{REFERENCES}

1. Ovat, F.A., David, F.O., Anyandi, A. J. Corrosion Behaviour of Al (6063) Alloy (As - Cast and Age Hardened) in $\mathrm{H}_{2} \mathrm{SO}_{4}$ Solution Journal of Materials Science Research 1 (4) 2012: pp. 35-40. https://doi.org/10.5539/jmsr.v1n4p35

2. Freitas, M., Pianaro, S.A., Nadal, F.N., Tebcherani, S.M., Berg, E.A.T. Preparation and Characterization of $\mathrm{SiC} /$ kaolin/Al Composite Materials by Squeeze- Casting Cerâmica 55 (335) 2009: pp. 27-280. http:doi.org/10.1590/S0366-69132009000300006

3. Torres, E., Arbeláez, J., Hincapié, D.A., Ramíre. A.J. Caracterización De Aleación De Aluminio AA6063 T5 Mediante Microscopía Óptica, Electrónica De Barrido Y Electrónica De Transmisión Revista Colombiana de Materiales 5 2014: pp. 59-64.

4. Camilo, D.C. Estudo Da Laminação Criogênica E Do Envelhecimento Natural Na Liga AA7050: Microestrutura E Propriedades, Master Thesis, Universidade Estadual de Ponta Grossa, Ponta Grossa/PR, 2013: pp. 126.

5. Ramirez, A.H., Ramirez, C.H., Costa, I. Cold Rolling Effect on the Microstructure and Pitting Resistance of the NBR ISO 5832-1 Austenitic Stainless Steel International Journal of Electrochemical Science 8 2013: pp. $12801-12815$.

6. Prabhu, D., Rao, P. Corrosion Behaviour of 6063 Aluminium Alloy in Acidic and in Alcaline Media Arabian 
Journal of Chemistry 10 2017: pp. S2234-S2244. https://doi.org/10.1016/j.arabjc.2013.07.059.

7. Garza, J.A.C. Deformación Plástica De Uma Aleación De Alumínio Tipo 6063, Master Thesis, Facultad de Inginiería Mecánica y Eléctrica, Universidad Autónoma de Nuevo León, San Nicolas de los Garza, México, 2009: pp. 175.

8. Gonçalves, R.A. Investigação da Usinabilidade Das Ligas De Alumínio Da Série 6xxx, Master Thesis, Universidade de Uberlândia, Uberlândia/MG, 2012: pp. 124.

9. Lins, J.F.C., Sandimb, H.R.Z., Raabec, D., Vecchio, K.S. Recristalização Dinâmica Em Bandas De Cisalhamento Adiabáticas Induzidas Num Aço IF III Workshop sobre Textura São Paulo 2006: 47-60.

10. Oliveira, T.R., Montheillet, F. Estudo da Recristalização Dinâmica Durante A Deformação A Quente Dos Aços
Inoxidáveis Ferríticos Estabilizados VII Seminário Brasileiro do Aço Inoxidável 2004: pp. 183-194.

11. Tan, C.F., Said, M.R. Effect of Hardness Test on Precipitation Hardening Aluminium Alloy 6061-T6 Chiang Mai Journal of Science 36 (3) 2009: pp. 276-286.

12. Holzle, L.R.B. Comportamento eletroquímico do alumínio em misturas etilenoglicol-água. Efeito da adição de agentes quelantes, f. Tese (Química), Universidade Federal do Rio Grande do Sul, Porto Alegre/RS, 2005: pp. 0136.

13. Bodunrin, M. O., Alaneme, K.K., Olusegun, S.J. Influence of Thermomechanical Processing on the Corrosion Behaviour of Aluminium (6063)-SiC Composites in $\mathrm{NaCl}$ and $\mathrm{H}_{2} \mathrm{SO}_{4}$ Environment Science Journal - Ubon Ratchathani University 2 (2) 2011: pp. 17-25. 